\title{
A Recruitment and Selection Process at Hi-Tech Civil Engineers Pvt.Ltd, Port Blair
}

\author{
R. Ramamoorthy, K. Venkatraman, M. Sangeetha
}

\begin{abstract}
Better enrollment and determination techniques bring about improved authoritative results. With reference to this unique situation, the exploration paper entitled Recruitment and Selection has been set up to put a light on Recruitment and Selection process. The fundamental target is to distinguish general practices that associations use to enlist and choose representatives and, to decide how the enrollment and choice practices influence authoritative results at SMC Global Securities Ltd. The examination procedure connected is the exploratory. The information was gathered through very much organized polls. The wellspring of information was both essential and auxiliary. Test size was 30. Information investigation has been finished with the assistance of SPSS programming. The organization thought about entries as the most significant vehicle of procuring workers. The representatives working in the organization consider the worker references are one of the most solid wellspring of contracting the new workers. Organization consistently takes in thought the money saving advantage proportion.
\end{abstract}

Keywords: Recruitment, Selection, Reference, Interview, Hiring, Performance.

\section{INTRODUCTION}

Enlistment is the way toward recognizing and drawing in a gathering of potential competitors from inside and outside the association for work. When these up-and-comers are distinguished, the way toward choosing proper representatives for business starts[1],[3],[5]. This implies gathering from different sources, estimating and assessing data about up-and-comers' capability for determined positions.

Drawing in new ability to the association is a key errand, particularly when the ability being referred to is hard to find. [2],[4],[6] Enrollment needs to have its spot inside the HR cycle as one methodology among others in a changing commercial center. Different methodologies, for example, creating current staff, ought not be ignored for outer enrollment. Enlistment ought to preferably not be centered proactively around bringing into the association the sort of aptitudes and experience, which can only with significant effort be worked from inside[7],[9],[11]. With too minimal

Revised Manuscript Received on July 22, 2019.

Mr. R. Ramamoorthy, Department of MBA, Bharath Institute of Higher Education and Research, Chennai, India.

Email: ramamoorthy0071@gmail.com

K. Venkatraman, Department of Civil Engineering, Bharath Institute of Higher Education and Research, Chennai, India.

Email: venkatraman.civil@bharathuniv.ac.in

M. Sangeetha, Department of MBA, Bharath Institute of Higher Education and Research, Chennai, India.

Email: sangeethagiri07.sg@gmail.com outside enrollment associations procedures and staff can begin to stagnate. Alternately, if enlistment from outside is the main methods by which senior positions are filled, inward competitors before long understand that they should leave the association, in the event that they need to be advanced. A well-structured enlistment procedure can draw in great competitors and give the business helpful signs of future execution[8],[10],[12]. Applicants are generally progressively positive about the association in the event that they can see an unmistakable connection between the enrollment procedure and occupation. Organized meetings, utilizing conduct and basic occurrence talking can be useful as they permit explicit employment related territories.

Pschycometrics, which is pertinent to the work content and sensible recreation, can likewise be valuable. Reenactment specifically enables directors to see a competitor's presentation from the outset hand[13], [15],[17].

Generally, the fruitful drawing in and enrolling of new ability implies that the necessities and offers of both the association and the individual should be coordinated. The 'fit' must be in right terms of aptitudes and experience just as qualities and necessities. It is accordingly significant that the two gatherings are educated beyond what many would consider possible all through the enlistment procedure. There will definitely be a procedure of exchange around those individual needs, generally overpaid or the sort of work and level of work which is on offer. In our inexorably mind boggling society, individuals have more instructive and improvement openings than any time in recent memory. This thusly has made an entirely different arrangement of worker desires and occupation goals, which cause steady loss in enterprises and employment opening.

Labor or HR is the most significant resource of any association and their viable administration is the way to the accomplishment of the association. Such a large number of organizations may likewise fill their labor prerequisites by at times re-appropriating through enrollment offices or consultancy firms. This is likewise a typical practice recently. There is consistently a necessity of expertly qualified and gifted staff in any association. With the expanding requests of the business, there isn't sufficient opportunity to get into the complexities of choosing an applicant. This is the place labor re-appropriating is finished[14],[16], [18].

The human asset branch of the association can list their activity opportunities in employment entrances like naukri.com, indeed.co.in, timesjobs.com, and so on and they may get reactions from reasonable and intrigued 


\section{A Recruitment And Selection Process at Hi-Tech Civil Engineers Pvt.Ltd, Port Blair}

up-and-comers. Along these lines, the HR office does not have bulky procedures and bothers for enlisting up-and-comers.

Finding the perfect individuals and putting them at the correct activity is the most testing activity of the HR branch of any association.

The HR staff peruse through heaps of competitor profiles, short-list applicants, call them, test their abilities as per the predetermined prerequisite and after that pass them on to their administration. There are sure aptitudes that are required for a specific sort of work. A Human asset proficient at an enlistment firm ought to have fantastic relational abilities, the capacity to pass judgment on individuals, a great intensity of understanding and getting a handle on. It is through this that the individual in question can choose possibility for the organization[19],[21],[23].

\section{A. Objectives}

- To study the different strategies for enlistment and determination.

- To study the different HR strategies in the organization.

- To know the sentiment of the representatives in regards to the organization's strategies.

\section{B. Need for the study}

- To update the enlistment practices embraced by the association.

- To locate the best strategies to get the correct possibility for the correct occupations.

- To get the most ideal talented workers for the organization.

- To discover best techniques for supplanting individuals when there is wearing down.

- To discover approaches to prepare and create existing staff for the activity opening[20],[22],[24].

\section{Limitations Of the study}

- The study is confined to taking the sentiment of workers of Hi-Tech Civil Engineers

- The respondents probably won't have offered their responses openly and honestly for the MCQ

- The representatives may be occupied with other work while the overview was directed

- The timeframe allocated for the venture is short.

\section{DATA COLLECTION}

The following are the statistical tools used in this project to arrive at specific results.

Percentage Analysis is a statistical tool which is used to identify the percentage of responses to the items in the questionnaire given by the respondents.

Percentage $=($ No. of respondents $/$ Total No. of samples $) \mathrm{x}$ 100.
Table - 1 Definition of position, objectives, requirement and candidate specification in recruitment process by the organization

\begin{tabular}{|l|l|l|}
\hline Category & Respondents & Percentage \\
\hline Yes & 60 & 75 \\
\hline No & 20 & 25 \\
\hline
\end{tabular}

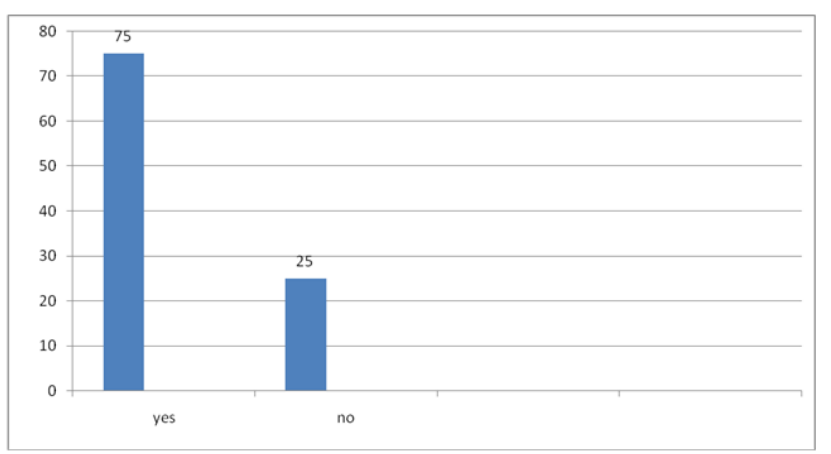

Table - 2 Organisation Doing Timeliness Recruitment Or Not

\begin{tabular}{|l|l|l|}
\hline Category & Respondents & Percentage \\
\hline Yes & 60 & 75 \\
\hline No & 20 & 25 \\
\hline
\end{tabular}

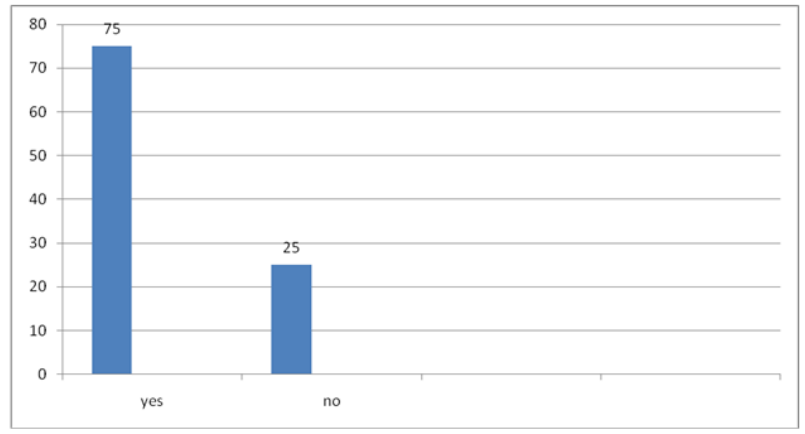

Table - 3 Hr Provides Adequate Pool Of Quality Applicants Or Not

\begin{tabular}{|l|l|l|}
\hline Category & Respondents & Percentage \\
\hline Yes & 40 & 50 \\
\hline No & 40 & 50 \\
\hline
\end{tabular}

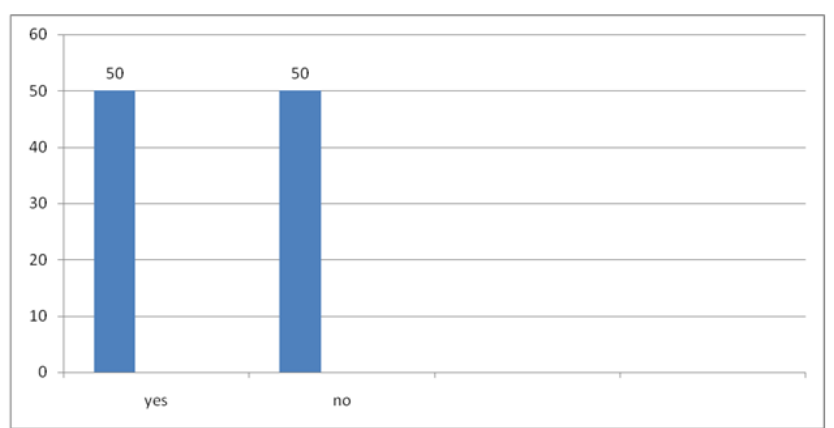

Table - 4 Rate Of Effectiveness Of The Interviewving Process And Testing 


\begin{tabular}{|l|l|l|}
\hline Category & Respondents & Percentage \\
\hline Poor & 10 & 12.5 \\
\hline Adequate & 30 & 37.5 \\
\hline Excellent & 40 & 50 \\
\hline
\end{tabular}

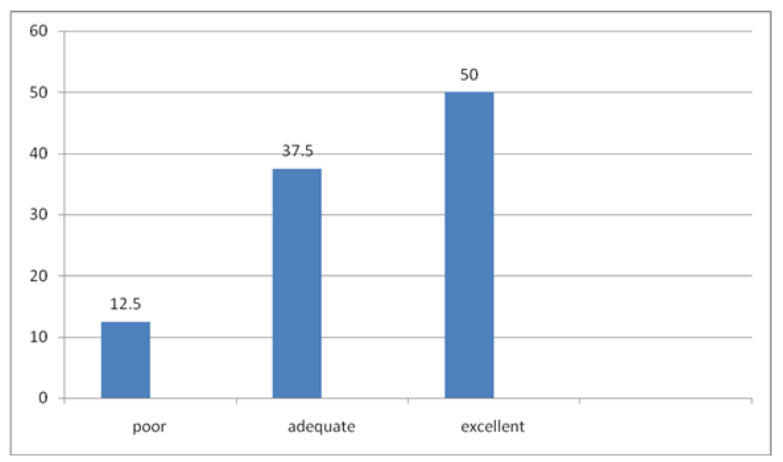

Table - 5 Hr Team's Role As Consultant To Enhance The Quality Of The Applicant Pre-Screening

\begin{tabular}{|l|l|l|}
\hline Category & Respondents & Percentage \\
\hline Yes & 50 & 62.5 \\
\hline No & 30 & 37.5 \\
\hline
\end{tabular}

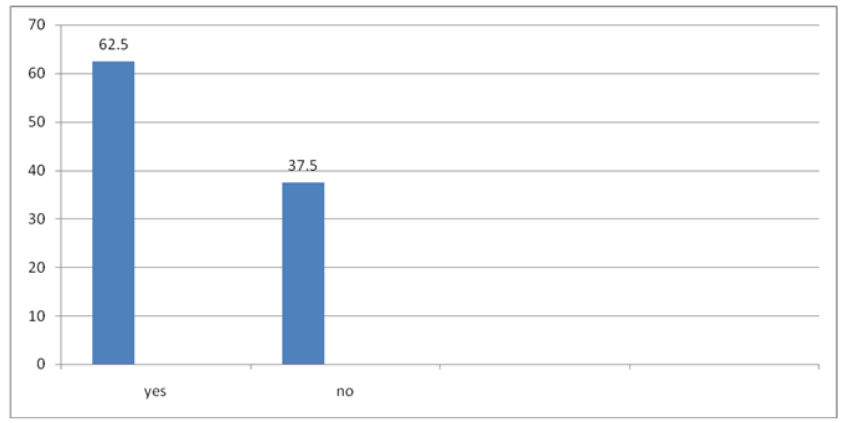

Table - 6 Rate Of Hr Department's Performance In Recruitment And Selection Process

\begin{tabular}{|l|l|l|}
\hline Category & Respondents & Percentage \\
\hline Poor & 10 & 12.5 \\
\hline Adequate & 30 & 37.5 \\
\hline Excellent & 40 & 50 \\
\hline
\end{tabular}

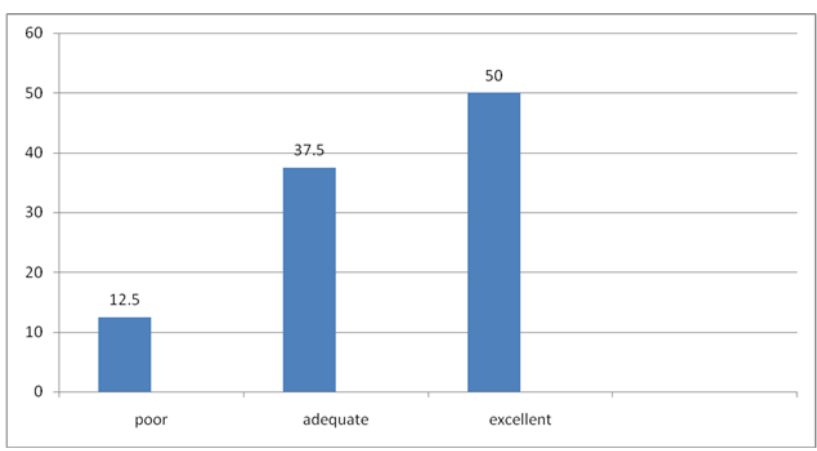

Table - 7 Company Takes Proper Feedback Or Not

\begin{tabular}{|l|l|l|}
\hline Category & Respondents & Percentage \\
\hline Yes & 40 & 50 \\
\hline No & 40 & 50 \\
\hline
\end{tabular}

- The company Hi-tech Civil Engineers Pvt. Ltd. has a good recruitment policy to ensure that the company gets the most suitable candidate for the particular job.

- The company HR recruits personnel as and when required through job portals and newspaper advertisements.

- For senior positions, the HR Manager prefers outsourcing to job consultants as they would have a wider database of experienced employees looking for a job change or higher post with higher salaries[25],[27],[29].

- Due to time constraints faced by the HR Department, the job vacancies are sometimes filled by outsourcing the requirements to job consultants.

- Existing present employees are asked to make Referrals when a job vacancy arises, so that the hiring process is less time-consuming and involves no costs.

- The job vacancies may be created due to attrition, when employees go in search of better jobs or companies, which offer higher salaries.

- For lower level jobs, candidates are selected directly or through referrals.

- Campus recruitments are very few.

- The major attributes that are considered before short-listing a candidate are qualification, experience, attitude and technical skill set.

\section{DISCUSSIONS}

The organization needs to utilize all accessible data and strategies accessible to them including the more conventional apparatuses of presence of mind and trustworthiness when settling on the privilege employing decisions for accessible opportunities.

- The organization should look inside preceding receiving any outer enrollment techniques.

- Have an unmistakable comprehension of the present commercial center including compensation, abilities deficiencies explanations behind contender to join the organization.

- There should an alternate procuring process for opening of various classes[26],[28],[30].

- There ought to be occupation profile or set of working responsibilities for each activity prerequisite.

- There ought to be a reasonable comprehension of the best techniques for drawing in workers, with better pay offers contrasted with contenders.

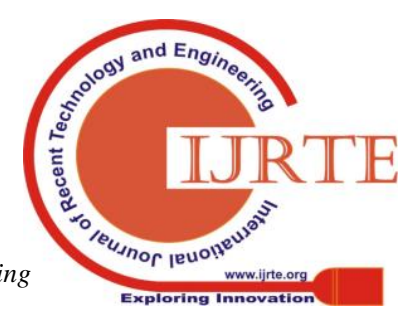


- The existing staff should present alluring maintenance measures and creating imaginative and inventive preparing projects to keep them roused and locked in.

- The organization should survey enrollment process yearly.

\section{V.SUGGESTIONS}

Enlisting can never again be limited to the conventional ways. With the war of ability strengthening, bosses are widening their span however inventive channels. Static enlistment never again gets the job done in the present setting of cost viability and productivity. HR experts have a major duty to procure a best competitor from the accessible sources talked about above. Simultaneously, one must be cost cognizant. No procedure is finished without an assessment of its prosperity. Occupation entries for workers of viable outer enlistment systems. Most associations have begun utilizing innovation to screen resumes, channel candidates and fabricate database for sometime later. In light of every single accessible datum, an ideal, practical, differing and versatile enlistment technique or system for enrollment can be landed at. Inner sourcing ought to likewise be finished by topping off the activity post with a reasonable inside up-and-comer[31],[33]. Resigned people could be given some expansion to complete the function admirably, as they would have long periods of experience. There ought to be reengineering forms, amplifying utilization of innovation to lessen expenses and adventure each wellspring of enrollment viably all evaluations and referrals are to be utilized to get best outcomes as they are the most

\section{REFERENCES}

1) BharthVajan R., Ramachandran S.,Psychographic dimensions of training,2016,International Journal of Pharmacy and Technology,V-8,I-4,P-23727-23729

2) Balakrishnan P., Bharthvajan R.,A study on human resource planning in hospitals in Chennai City,2014,International Journal of Applied Engineering Research,V-9,I-22,P-7503-7507

3) Priyadarsini P., Bharthvajan R.,Role of emotional intelligence training programme in reducing the stress of the nurses,2014,International Journal of Applied Engineering Research,V-9,I-22,P-7411-7421

4) Kerinab Beenu G., Bharthvajan R.,Empirical analysis on the cosmetic buying behavior of young women in South India,2014,International Journal of Applied Engineering Research,V-9,I-22,P-7361-7366

5) Balakrishnan P., Bharthvajan R.,Whistling in the wind,2014,International Journal of Applied Engineering Research,V-9,I-22,P-7586-7593

6) Krishnan B., Peter M.,Health hazards of Indian Bpo employee-an alarming issue,2014,International Journal of Applied Engineering Research,V-9,I-22,P-7336-7341

7) Kerinab Beenu G.H., Peter M.,Role of insurance in economic development,2014,International Journal of Applied Engineering Research,V-9,I-22,P-7532-7539

8) Balakrishnan P., Peter M., Priyadarsini P.,Efficiency of safety measures for wellbeing of employees in manufacturing industry,2014,International Journal of Applied Engineering Research,V-9,I-22,P-7376-7382

9) Anbarasi M., Praveen Kumar S.,Online sales promotions of herbal products and its effectiveness towards tanisha.com,2019,Indian Journal of Public Health Research and Development,V-10,I-1,P-195-200

10) Anbarasi M., Praveen Kumar S., Various online marketing and promotions strategies to improve the validation towards the organic products in the pharmaceutical sectors, 2019,Indian Journal of Public Health Research and Development,V-10,I-1,P-263-269

11) Loganathan R., Praveen Kumar S.,Grievance handling a key factor for solving issues of employees in an organization,2014,International Journal of Applied Engineering Research,V-9,I-22,P-7483-7491
12) Loganathan R., Praveen Kumar S.,Study on preference of private label brands in super and Hypermarkets,2014,International Journal of Applied Engineering Research,V-9,I-22,P-7327-7335

13) Smitha M., Praveen Kumar S.,Understanding stress and its managementamong the nurses in Chennai city,2014,International Journal of Applied Engineering Research,V-9,I-22,P-7560-7565

14) Kerinab Beenu G.H., Praveen Kumar S.,A study on the investment behavior of Chennai investors in mutual fund schemes,2014,International Journal of Applied Engineering Research,V-9,I-22,P-7520-7525

15) Loganathan R., Praveen Kumar S.,Retention strategies key for organizational productivity,2014,International Journal of Applied Engineering Research,V-9,I-22,P-7443-7447

16) Pavithra J., Ganesan M., Brindha G.,State wise analysis of microfinance sector in India,2016,International Journal of Pharmacy and Technology,V-8,I-4,P-23417-23432

17) Pavithra J., Ganesan M.,A comparative study on microfinance in India and abroad,2016,International Journal of Applied Business and Economic Research,V-14,I-8,P-5471-5476

18) Pavithra J., Ganesan M.,A study on awareness and impact of micro-financial schemes,2016,International Journal of Applied Business and Economic Research,V-14,I-8,P-5449-5460

19) Senthilmurugan P., Pavithra J.,Consumer preference towards organised retailing with reference to Big Bazaar,2014,International Journal of Applied Engineering Research,V-9,I-22,P-7469-7475

20) Senthilmurugan P., Pavithra J.,Implication of social media marketing in growing healthcare industry,2014,International Journal of Applied Engineering Research,V-9,I-22,P-7448-7456

21) Loganathan R., Pavithra J.,Consumer perception towards private label brand over other brands in super markets and hypermarkets,2014,International Journal of Applied Engineering Research,V-9,I-22,P-7355-7360

22) Kerinab Beenu G., Pavithra J.,Tradeâ€"off between liquidity and profitability in logistics industry,2014,International Journal of Applied Engineering Research,V-9,I-22,P-7398-7401

23) Kerinab Beenu G., Pavithra J.,A study on the prospective consumerâ€ ${ }^{\mathbf{T M}_{\mathbf{S}}}$ perception towards utility cars in Chennai city,2014,International Journal of Applied Engineering Research,V-9,I-22,P-7526-7531

24) Pavithra J., Dilli Babu P., Ambuli T.V.,A study on budgetary control at Maruti Service Masters, Chennai,2014,International Journal of Applied Business and Economic Research,V-12,I-2,P-151-161

25) Pavithra J., Dilli Babu P., Ambuli T.V.,A study on customer satisfaction of retro Garments Pvt Ltd, Chennai,2014,International Journal of Applied Business and Economic Research,V-12,I-2,P-381-391

26) Kerinab Beenu G.H., Pavithra J., Senthilmurugan P.,A study on the influence of promotional activities for TATA ARIA among consumers in Chennai,2014,International Journal of Applied Engineering Research,V-9,I-22,P-7572-7578

27) Vijayaragavan S.P.,An investigative expert that's general FBG sensors,International Journal of Mechanical Engineering and Technology,V-8,I-8,PP-1500-1505,Y-2017

28) Vijayaragavan S.P.,Equalization routing protocol for Wi-Fi sensor strategy,International Journal of Mechanical Engineering and Technology,V-8,I-8,PP-1662-1666,Y-2017

29) Karthik B., Kiran Kumar T.V.U., Vijayaragavan P., Bharath Kumaran E.,Design of a digital PLL using 0.35 $\hat{\mathrm{I}}^{1} / 4 \mathrm{~m}$ CMOS technology,Middle East Journal of Scientific Research,V-18,I-12,PP-1803-1806,Y-2013

30) Kanniga E., Selvaramarathnam K., Sundararajan M.,Kandigital bike operating system,Middle - East Journal of Scientific Research,V

31) Jasmin M., Vigneshwaran T., Beulah Hemalatha S.,Design of power aware on chip embedded memory based FSM encoding in FPGA,International Journal of Applied Engineering Research,V-10,I-2,PP-4487-4496,Y-2015

32) Jasmin M.,Optimization techniques for low power VLSI circuits,Middle East Journal of Scientific Research,V-20,I-9,PP-1082-1087,Y-2014

33) Jasmin M., Vigneswaran T.,Fuzzy controller for error control of on - Chip communication,2017 International Conference on Algorithms, Methodology, Models and Applications in Emerging Technologies, ICAMMAET 2017,V-2017-January,I-,PP-1-5,Y-2017 


\section{AUTHORS PROFILE}

Mr. R. Ramamoorthy Assistant Professor, Department of MBA, Bharath Institute of Higher Education and Research, Chennai, India.

K. Venkatraman Assistant Professor, Department of Civil Engineering, Bharath Institute of Higher Education and Research, Chennai, India.

M. Sangeetha Student, Department of MBA, Bharath Institute of Higher Education and Research, Chennai, India. 